\title{
The Impact of Financial Disruption on Indian Students Planning Higher Education in and Outside Home Country, with Special Reference to SBI Education Loan
}

\author{
Ms. PrathibhaVikram, Research Scholar, VTU, Assistant Professor, Jain University, India.
}

ABSTRACT - India has tackled large-scale reform to improve student ratio in higher education as a remarkable career based path. The expanding capacity for doctoral students at research universities and breakup for educational qualifications for teaching eligibility raising the standards during the recent decades reflects the growth aspect of higher education in India. India has been able to overcome the learning outcomes and enrolment numbers with a student-centric learning-driven model of education. The landscape of India's higher education has modified during the last two decades. This paper studies the growth of finance offered for diploma courses, under graduation, post graduations within and outside India. Education Loans play a vital role in the flowing system of advances and the growing demand for quality education in the current job market. The demand for education loan seeker and the supply of funds from the financial institutions has seen a lot of variations due to the disruption in the recovery ratio. A detailed study on Education Loan Interest Rate, Loan Tenure, Loan Amount and Pre-closure Charges are the highlights of this paper along with loan sanctioned and loan disbursed for students studying within India and abroad regarding the SBI Education Loan data.

Keywords- India, Education Loan, Financial disruption, Financial Disruption, Recovery Ration.

\section{INTRODUCTION}

Education is the process of building knowledge, skills, values, beliefs and habits implemented for a learner.Effective education is a learning experience. Education brings about an inherent and permanent change in a human's thinking and capacity to do things. There is no escaping from the fact that good learning takes time. Reading a book and understanding what you read, does not mean that you have been educated (or permanently changed), if you don't integrate what you read into your attitudes and memory. The term educated is not just attending a lecture or attending a course. The real education is very different from just acknowledgementof information about something. Real education inherent the brain of a learner and someone who is aware of what is learning will agree that real education roots from repeated exposure and use of skills and information.

Loan is a term which refers to money lending process, in exchange for future repayment of the value of the loan amount, along with interest or the other charges. A loan may be for a specific purpose which is usually a one-time amount or an open-ended line of credit to a specified amount. Loan may be a limited amount for various purposes which may be the basic need of the person who requires that specified amount. A lender may be an individual, a corporation, a financial institution or even government. The lending process in India is a practice from generations and is of perpetual nature. The fees charged or the interest collected for the money given as loan act as primary source of revenue for the lender. The terms of a loan are agreed to by both the parties entering the transaction. If the lender wants to maintain some security for the amount rendered as loan, it may be discussed between the parties and outlined in the loan document. The maximum amount of interest and the period of repayment should also be the highlighted in the loan document.

A written or oral agreement for a temporary transfer of money from its owner (the lender) to a borrower who promises to return it according to the terms of the agreement, usually with interest for its use is termed as loan. The demand loan is the loan repaid on the demand of the lender. The money to be repaid can be in monthly equal installments and is referred to as installment loan. The classification of loans depends on the purpose the money is required, some loans serve the commercial purpose and some serve the industrial purpose.

One such purpose oriented loan for younger generation with zero income is Educational Loan provided for the students planning higher education. This is a special type 
of loan and the reason to term it special is the deferred payment mode. Education loan issued for a student, for the purpose of enhancing higher education can be availed after their completion of under graduate degree. Payment of these loans is often deferred while students are in college and for a grace period after they complete their course of graduation or post-graduation. These loans can be acquired from government or through private-sector lending sources. Education loans seems to be a blessing to the student who is aiming at higher standards in upgrading his/her knowledge but at the same time is a challenge for the lender due to the deferred payment mode which makes the repayment risk very high.

\section{Literature REVIEW}

The literature review examines the historically significant research studies parallel with the recent reports that act as the basis for the proposed research work. The literature review examines the need for the proposed work to appraise the shortcomings and informational gaps in the existing resources.

Jandhyala B. G. Tilak and N.V. Varghese, "Financing higher education in India", (1992), in their paper attempt to analyze the present pattern of funding in higher education in India and the feasibility of various alternative methods of funding. The government has to continue to carry on the responsibility of funding higher education which will help in the growth of economy as a whole. This paper reveals the efforts made to evolve a model of funding which in turn provides a mix of various methods. Funding higher education from government should shape itself for the socioeconomic and political realities instead of relying on a single form of funding.

SanatKaul, "Higher education in India: Seizing the opportunity", (2006) in the research working paper, No. 179, Indian Council for Research on International Economic Relations (ICRIER), mentioned that the $\mathrm{KPO} / \mathrm{BPO}$ boom in India will be rendered as a mere accident, unless we Indians are able to provide sufficient skilled manpower to keep up the advantage. The Government must step in to facilitate the enabling environment for higher production of skilled manpower in India; else we shall swiftly lose out to other countries.

Alan Sanchez and Abhijeet Singh, "Accessing higher education in developing countries: Panel data analysis from India, Peru and Vietnam", (2016), in their article express the unique individual-level panel data from South India, especially Andhra Pradesh, Peru and Vietnam on the group of individuals surveyed from the age of 8 years to 19 years to study the factors affecting enrolment in higher education in these middle-income countries. They also mention about the gender gaps in India (pro-male) and Vietnam (pro-female).
P.S.Aithal, Srinivas Institute of Management Studies and P.M. Kumar, Srinivas Institute of Management Studies, "Analysis of choice based credit system in higher education", (2016), speaks about the two higher education systems which are expected to be attractive to the learners - Choice based credit system and Competency based credit system. The Choice Based Credit System (CBSC) is a choice provided to students to choose the course of their choice. It adds value to the specialization and skill the student needs to progress and keeps up-to-date with the development of higher education in India and abroad. CBCS aims to redefine the curriculum keeping pace with the liberalization and globalization in education.

Arindam Bandyopadhyay (2016) studied through an investigation that the level of risk in education loan is influenced by security, borrower margin and repayment periods. The research paper was conducted using a cross section of data from 5000 borrowers procured from four major public sector banks in India. The suggestions segmented that the borrowers default in a multidimensional scale can be resolved through the banks by balancing the pricing strategies and risk mitigation.

\section{RESEARCH GAP}

There are a lot of studies on the growth of debt issues related to education loan but none of them correlating the loan with the growth rate of increase or decrease in the number of students applying for the loan. The study on education loan is made by many research scholars for one region for the available frommany banks but not made for in comparison with the same bank all over India. The gap is identified by examining the trend of educational loan by the report generated by SBI Education Loan.

\section{Statement of the Problem}

For many years, the population of India has been growing and so is the education sector. But the population growth rate is moving in a different pace with the education growth rate are not colliding parallel in the same pace. The growth rate of young generation (Gen Z) eligible for higher education may not be enrolling for the same due to various reasons. The financial disruption aroused due to the education loan will affect the Indian Banks' NPAs, the growing student debt level and debt recovery ratio needs to be examined.

\section{Objective of the Study}

On the basis of reviewed studies, it can be stated that number of studies have been conducted to verify the various loans with different maturity periods. But very few studies have been carried on in which the growth rate of education loan is compared. Accordingly, the study aims at analyzing the movement of demand by different States in India for loan and the actual loans disbursed.The gap is identified by examining the trend of educational loan by 
the report generated by SBI Education Loan. Besides, it aims at understanding the impact of year-on-year variations in the demand trends compared to students studying in India and Abroad. Therefore, the objectives are as under:

- To analyze the trend of education loan in major states in Indiafor the past three years.

- To examine the galvanizing nature of default risk prevailing in education loan.

\section{RESEARCH Methodology}

This is a conceptual study and descriptive study based on secondary data collected from books, journals, magazines, newspapers and the internet.

\section{Analysis}

The quality of manpower is the key factor of economic growth for any country apart from natural resources, technology and capital. The performance of a country can be acknowledged by the quality of manpower. Good quality higher education will enhance this requirement of economic growth for a country. The human capital formation is based on the knowledge attained by the population and the dimension of the population to use this knowledge effectively.

There are large-scale reforms worked over India to better the ratio between faculty and students by making teaching an appealing career path. India has also elaborated the capacity for doctoral students at research universities and ramified educational qualifications from teaching eligibility. India has undertaken huge constructional and methodical changes that have started to yield inspiring results. The country has been touted to have the best-inclass post-secondary education system at present. The major factors that have contributed to this growth and can help envision the 2030 dream includes:

- Augmentation of a transformed university system with a three-tiered formalized structure

- Transition to a learner-centered paradigm of education

- Intensive use of technology

- Reforms in governance

\section{Education Loan in India:}

Loan for Higher Education is dedicated to students and Vidya Lakshmi was the first Central IT-based portal for students seeking Education Loan. The Department of Higher Education, Department of Financial Services and Indian Banks Association supported in developing this portal and guided the path. The path paved way to NSDL e-Governance Infrastructure Limited to develop and maintain this portal dedicated to education. It is a portal open for students where they get to view, apply and track the education loan application by banks with ubiquitous nature. The portal not only provides anytime anywhere access, but also provides link to Scholarship portals.

The scheme focuses on the following terms mention below:

- For loans up to Rs. 4 lakhsguarantee or margin is NOT required and the interest rate should not exceed the Prime Lending Rates (PLR). For loans above Rs. 4 lakhs the interest rate will not exceed PLR plus 1 percent.

- The repayment of loan has a provision of grace period of one year after completion of studies and may repay it within 5 to 7 years.

The Ministry of Finance posted a press release on $24^{\text {th }}$ June 2019 by Press Information Bureau, Delhi and as per this Circular, the Reserve Bank of India (RBI) mapped by Indian Banks' Association (IBA) advised all Scheduled Commercial Banks to adopt Education Loan Scheme. IBA articulated and spread across to all its members to assist financial support to laudable students pursuing higher education.

\section{Salient features of the Scheme inter-alia include:}

I. For students studying in India loan up to Rs 10 lacs and for students studying abroad up to Rs 20 lacs.

II. The Credit Guarantee Fund Scheme for Education Loans (CGFSEL) with Collateral free loans up to Rs 7.5 lacs.

III. No Margin for loan up to Rs 7.5 lacs.

IV. The period considered for repayment period is 15 years.

V. Moratorium for repayment after completion of studies in all cases is one year,

VI. During the life cycle of the loan, the moratorium taken into account spells of unemployment/underemployment, say two or three times.

VII. If the student wants to take up a start-up venture after graduation, then the moratorium for the incubation period is considered.

\section{Tax Benefit (u/s 80E)}

Some specific loans provide a tax shelter during repayment process. Education loan repayment is also availed under Section $80 \mathrm{E}$ of the Income Tax Act and the limit for deduction annually is Rs. 40,000 (for both the principal and the interest). Only loans taken for higher education - full time studies in any graduate or postgraduate, professional, and pure and applied science courses - may claim deduction. The deductions can be claimed only after the repayment process begins and this deduction can be claimed for 8 years once the repayment 
process gets started. Under the guidelines of RBI, IT Act claims that interest subsidy can be claimed while filing the Income Tax. The Central Sector Interest Subsidy Scheme, 2009, provides complete interest subsidy during the moratorium period for economically weaker section.

\section{Educational Loan Schemes}

University Grants Commission (UGC) manifested the quality of higher education to access equally. UGC encourages the universities and colleges to provide financial support for the needy and meritorious students. It is also involved and actively participating in the Educational Loan Scheme. The Commercial Banks provide this loan under the guidelines provided by the Reserve Bank of India. Education Loan Scheme is launched by Scheduled Banks. The names of the Private Banks are provided below along with the individual offering for such facilities are Bank of Baroda - BOB Scholar Scheme, Bank of India - Vidya Vardhini, Canara Bank - Vidya Sagar Loan, Central Bank of India - Cent Vidhyarthi, Dena Bank - Dena Vidya Laxmi, Indian Overseas Bank - Vidya Jyothi, Oriental Bank of Commerce - Educational Loan Scheme, Punjab National Bank - Vidyalaksyapurti Scheme, Syndicate Bank - Synd Vidya, UCO Bank - Educational Loan Scheme, Union Bank of India - Synd Vidya and many more.

Annexure - I: State-wise Education loans sanctioned by the SBI for pursuing degree and diploma courses inside and outside the country during each of the last three years and the previous year 2019

\begin{tabular}{|c|c|c|c|c|c|c|c|c|c|c|c|c|c|c|c|c|}
\hline \multirow[t]{3}{*}{ STATENAIIE } & \multicolumn{4}{|c|}{ FY-16-17 } & \multicolumn{4}{|c|}{ FY-17-18 } & \multicolumn{4}{|c|}{ FY-18-19 } & \multicolumn{4}{|c|}{$\begin{array}{l}\text { Amount in Crore } \\
\text { FY-19-20 (upto 14.0619) }\end{array}$} \\
\hline & \multicolumn{2}{|c|}{ Studies in India } & \multicolumn{2}{|c|}{ Studies Abroad } & \multicolumn{2}{|c|}{ Studies in India } & \multicolumn{2}{|c|}{ Studies Abroad } & \multicolumn{2}{|c|}{ Studies in India } & \multicolumn{2}{|c|}{ Studies Abroad } & \multicolumn{2}{|c|}{ Studies in India } & \multicolumn{2}{|c|}{ Studies Abroad } \\
\hline & No. & Amit & No. & Amt & No. & Amit & No. & Amat & No. & Amt & No. & Amit & No. & Amit & No. & Amt \\
\hline ANDAMAN AND & & & & & & & & & & & & & & & & \\
\hline ANDHRA PRADESH & 2947 & 163.97 & 1536 & 310.05 & 3249 & 185.60 & 1059 & 241.55 & 5391 & 387.08 & 1728 & 42092 & 755 & 79.09 & 184 & 53.05 \\
\hline $\begin{array}{l}\text { ARUNACHAI } \\
\text { PRADBSH }\end{array}$ & 27 & 0.89 & 0 & 0.00 & 40 & 1.40 & 2 & 0.21 & 34 & 1.42 & 1 & 0.21 & 9 & 0.44 & 0 & 0.00 \\
\hline ASSAM & gor & 39.41 & 101 & 22.13 & 1114 & 36.25 & 124 & 25.10 & 8sou & $4 \pi / 1$ & 100 & 20.20 & 152 & 8.05 & 9 & 185 \\
\hline BIHAR & 1939 & 81.54 & 80 & 15.30 & 4642 & 101.10 & 124 & 21.05 & $\frac{1082}{102}$ & 30.17 & 89 & 2121 & 98 & $8.4 \%$ & 15 & $45 y$ \\
\hline $\begin{array}{l}\text { CHANDIGAKR } \\
\text { CHATIISGAKH }\end{array}$ & $\frac{135}{1027}$ & $\frac{1000}{44000}$ & 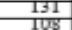 & 21.83 & $\frac{122}{1035}$ & $\frac{1.19}{31.40}$ & $8 \pi$ & 18.81 & 102 & $\frac{12600}{4530}$ & 121 & 20.45 & 31 & 402 & 23 & $\frac{719}{352}$ \\
\hline DADRA AND NAGAR & & & & 28.23 & & 0.2 .70 & & & & & & & 204 & 12.74 & & \\
\hline $\begin{array}{l}\text { HAVELI } \\
\text { DANLANANDDIU }\end{array}$ & $\frac{4}{3}$ & $\frac{0.37}{0.17}$ & $\frac{1}{2}$ & $\frac{0.20}{0.34}$ & $\frac{4}{7}$ & $\frac{0.22}{0.44}$ & 5 & $\frac{0.00}{1.24}$ & $\frac{13}{5}$ & $\frac{0.87}{039}$ & $\frac{2}{8}$ & $\frac{0.79}{1.32}$ & 4 & $\frac{0.44}{0.00}$ & 1 & $\frac{0.18}{0.00}$ \\
\hline DEIHI & 1452 & 93.74 & 422 & 107.45 & 1635 & 111.40 & 439 & 113.64 & 1399 & 10714 & 395 & 113.79 & 229 & 25.08 & 38 & 2194 \\
\hline GOA & 209 & 19.01 & 29 & 4.74 & 284 & 31.42 & 37 & 8.17 & 407 & 5094 & 29 & 8.25 & 72 & 9.34 & 4 & 175 \\
\hline GUMRT & $\frac{1357}{825}$ & $\frac{125.89}{40.9}$ & $\frac{517}{314}$ & 104.57 & 2052 & 168.38 & 910 & 195.65 & 2336 & 243.01 & 1314 & 289.48 & $\frac{570}{270}$ & 89.68 & 296 & 7000 \\
\hline $\begin{array}{l}\text { HARYANA } \\
\text { HIMACHAL PRADESH }\end{array}$ & $\frac{832}{463}$ & $\frac{49.29}{20.99}$ & $\frac{314}{11}$ & $\frac{67.17}{10.59}$ & $\frac{1027}{448}$ & $\frac{74.47}{23.09}$ & $\frac{324}{74}$ & $\frac{78.10}{12.35}$ & $\frac{1035}{389}$ & $\frac{7498}{2098}$ & $\frac{405}{92}$ & $\frac{113.81}{1795}$ & $\frac{229}{68}$ & $\frac{26.10}{5.39}$ & $\frac{79}{13}$ & $\frac{1882}{215}$ \\
\hline JANDIU AND RASHMIIR & 140 & 7.20 & 53 & 10.11 & 175 & 12.41 & 46 & 8.65 & 126 & 8.70 & 61 & 11.14 & 17 & 129 & II & 132 \\
\hline JHALKKHANDD & 2035 & 142.21 & $1 / 3$ & 10.35 & 1810 & 132.22 & 63 & 15.95 & 1085 & $15 \% 03$ & 69 & IS.91 & 284 & 36.53 & 13 & 5.29 \\
\hline RAIRNATIAKA & 3912 & 160.35 & 1291 & 355.25 & 3439 & 10.02 & g90 & 305.7 & 3850 & 22020 & IIUS & 305.95 & 610 & 39.10 & 251 & 8956 \\
\hline KEREALA & ogsy & $\frac{10.42}{281.42}$ & 801 & I01.10 & 4999 & $\frac{19.19}{219}$ & 842 & 183.59 & 60005 & 509.0 & 1405 & 302.39 & 1443 & 79.12 & 352 & प्रा.04 \\
\hline 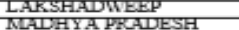 & & $\frac{0.00}{15221}$ & & $\frac{0.00}{0.10}$ & $\frac{1}{2017}$ & $\frac{0.07}{1430}$ & 349 & $\frac{0.00}{8545}$ & $24 \%$ & $\frac{0.00}{1082}$ & 341 & $\begin{array}{ll}0.00 \\
\end{array}$ & 313 & 000 & का & 000 \\
\hline MLAHARASHIKA & 3201 & 243.05 & $14 / 4$ & 304.25 & 3000 & 245.19 & 1505 & 3.9 .14 & 6108 & 340.45 & $\frac{341}{145 !}$ & 405.40 & $\begin{array}{l}328 \\
428\end{array}$ & $\frac{85.19}{85.19}$ & 194 & $\frac{18.02}{61.65}$ \\
\hline MALNIPUR & 31 & 1.49 & 8 & 0.77 & 35 & 1.36 & 9 & 1.03 & 48 & 187 & & 0.83 & 2 & 0.11 & 1 & 010 \\
\hline NEGHAI AYA & 359 & & 10 & 1.64 & 353 & 20.34 & 16 & 3.26 & 267 & 16.48 & & 137 & 15 & 0.88 & & 0,00 \\
\hline MIZORAM & 11 & 0.34 & 0 & 0.00 & 12 & 0.36 & 0 & 0.00 & $\frac{6}{7}$ & 0.21 & $\frac{3}{5}$ & 0.56 & 0 & 0.00 & 1 & 0.14 \\
\hline $\begin{array}{l}\text { NAGALAND } \\
\text { ODISHA }\end{array}$ & $\frac{29}{1304}$ & $\frac{1.01}{85,25}$ & 85 & $\frac{0.00}{1864}$ & $\frac{31}{1241}$ & $\frac{1.18}{71.10}$ & $\frac{2}{9}$ & $\frac{0.28}{1994}$ & $\frac{17}{1799}$ & $\frac{0.68}{12537}$ & $\frac{5}{98}$ & 2598 & का & 6.12 & 13 & $\frac{000}{55}$ \\
\hline PONDICHERRY & $\frac{1504}{82}$ & $\frac{8.25}{3.87}$ & $\frac{8}{32}$ & 6.44 & $\frac{1241}{117}$ & $\frac{1.100}{5.00}$ & 13 & $\frac{19.94}{2.81}$ & $\frac{159}{248}$ & $\frac{1.32}{10.62}$ & 31 & $\frac{2.38}{8.18}$ & $\frac{303}{42}$ & 192 & $\frac{9}{9}$ & 168 \\
\hline PUNJAB & 866 & 50.17 & 919 & 119.53 & 653 & 42.54 & 502 & 78.45 & 77 & 81.77 & 628 & 108.77 & 182 & 2525 & 113 & 1987 \\
\hline RAIASTHAN & 2352 & 146.32 & 212 & 44.22 & 1762 & 123.10 & 233 & 62.94 & 1806 & 145.04 & 310 & 81.59 & 247 & 22.65 & 49 & 1470 \\
\hline SIKKIMI & $\frac{11}{3015}$ & 0.10 & 3 & 0.60 & 15 & 0.61 & $\frac{2}{84}$ & 0.40 & $\frac{12}{3414}$ & 0.45 & प्रपा & 0.05 & $\frac{1}{12}$ & 0.04 & 0 & 000 \\
\hline IELALNGANAA & 1850 & $15 \% .14$ & 1810 & 331.35 & 2000 & $1 / 4.29$ & 1050 & 221.14 & 2017 & $\frac{117-97}{21320}$ & 1451 & $\frac{58502}{5802}$ & $\frac{1202}{354}$ & 41.45 & $\frac{184}{184}$ & $\frac{4535}{5430}$ \\
\hline IRIP & $18 \%$ & & & & 140 & 0.45 & 5 & & 150 & 2.19 & & $1 / 8$ & 29 & 0.95 & 0 & 000 \\
\hline UTTARP & 2211 & 145.19 & 247 & 36.18 & 2292 & 104.12 & 209 & 68.48 & 2395 & 1928 & 200 & 75.50 & 340 & 35.99 & 45 & 12001 \\
\hline UTTAS & 783 & 48.01 & 84 & 18.28 & 858 & 80.14 & 82 & 18.84 & 805 & 6154 & I0I & 21.47 & प्र2 & 7.85 & 15 & 431 \\
\hline WEST BENGAL & $\frac{2593}{49127}$ & $\frac{147.30}{2542,28}$ & $\frac{178}{11041}$ & 33.01 & $\frac{2662}{49360}$ & 161.68 & $\frac{193}{10154}$ & $\frac{41.11}{24562.9}$ & $\frac{2573}{54109}$ & $\frac{17641}{354454}$ & $\frac{211}{13025}$ & $\frac{50.54}{303055}$ & 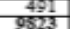 & $\frac{4521}{90218}$ & 34 & 61651 \\
\hline $\begin{array}{l}\text { Grand Total } \\
\text { Source: SBI }\end{array}$ & & & & & & & & & & & & & & & & \\
\hline
\end{tabular}

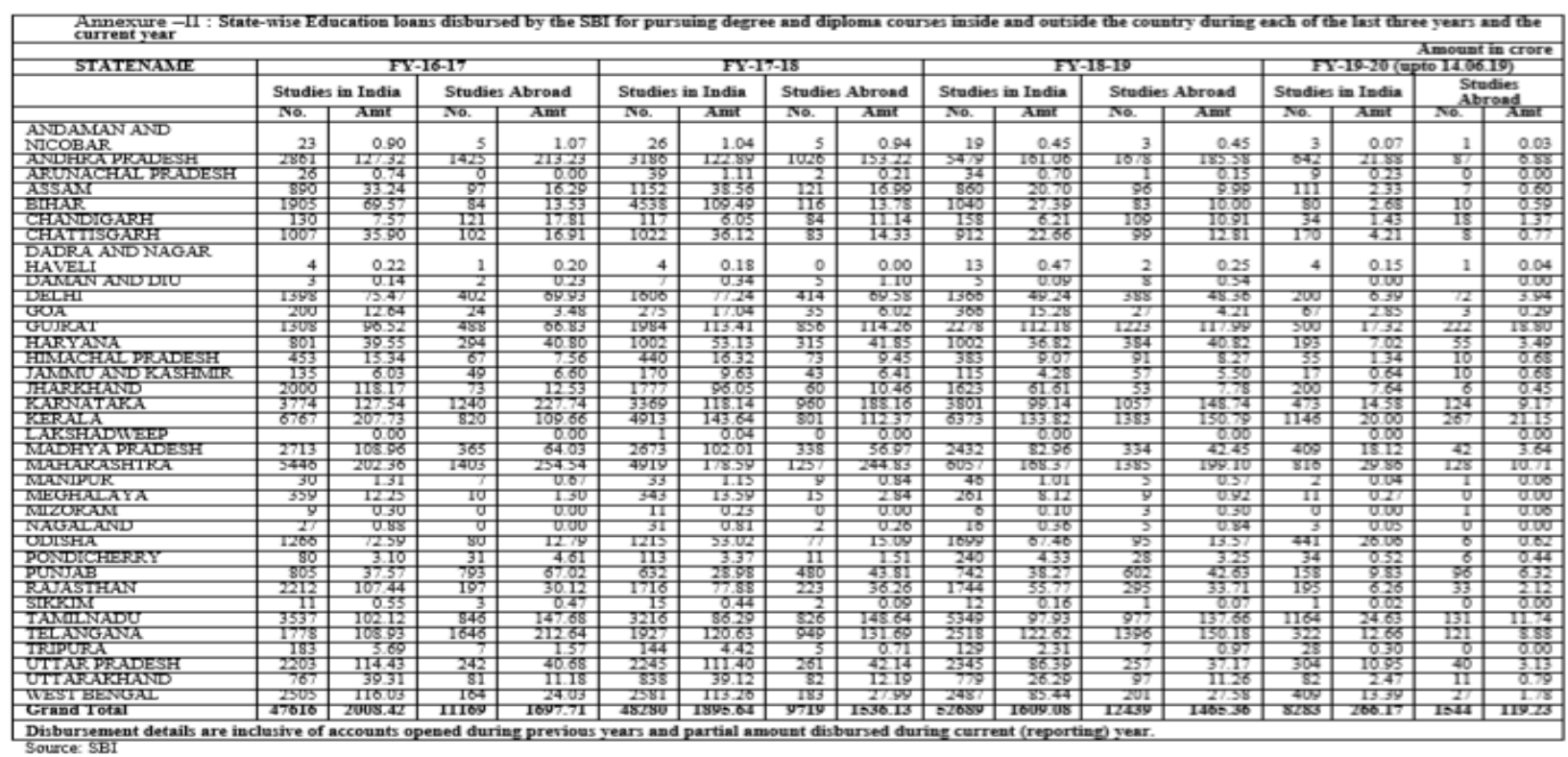


* Other States include the remaining 21 States of India - Chhattisgarh, Manipur, Andaman and Nicobar, Arunachal Pradesh, Assam, Pondicherry, Bihar, Chandigarh, Jammu and Kashmir, Dadra and Nagar Haveli, Daman and Diu, Goa, Himachal Pradesh, Lakshadweep, Meghalaya, Mizoram, Nagaland, Punjab, Sikkim, Tripura and Uttarakhand.
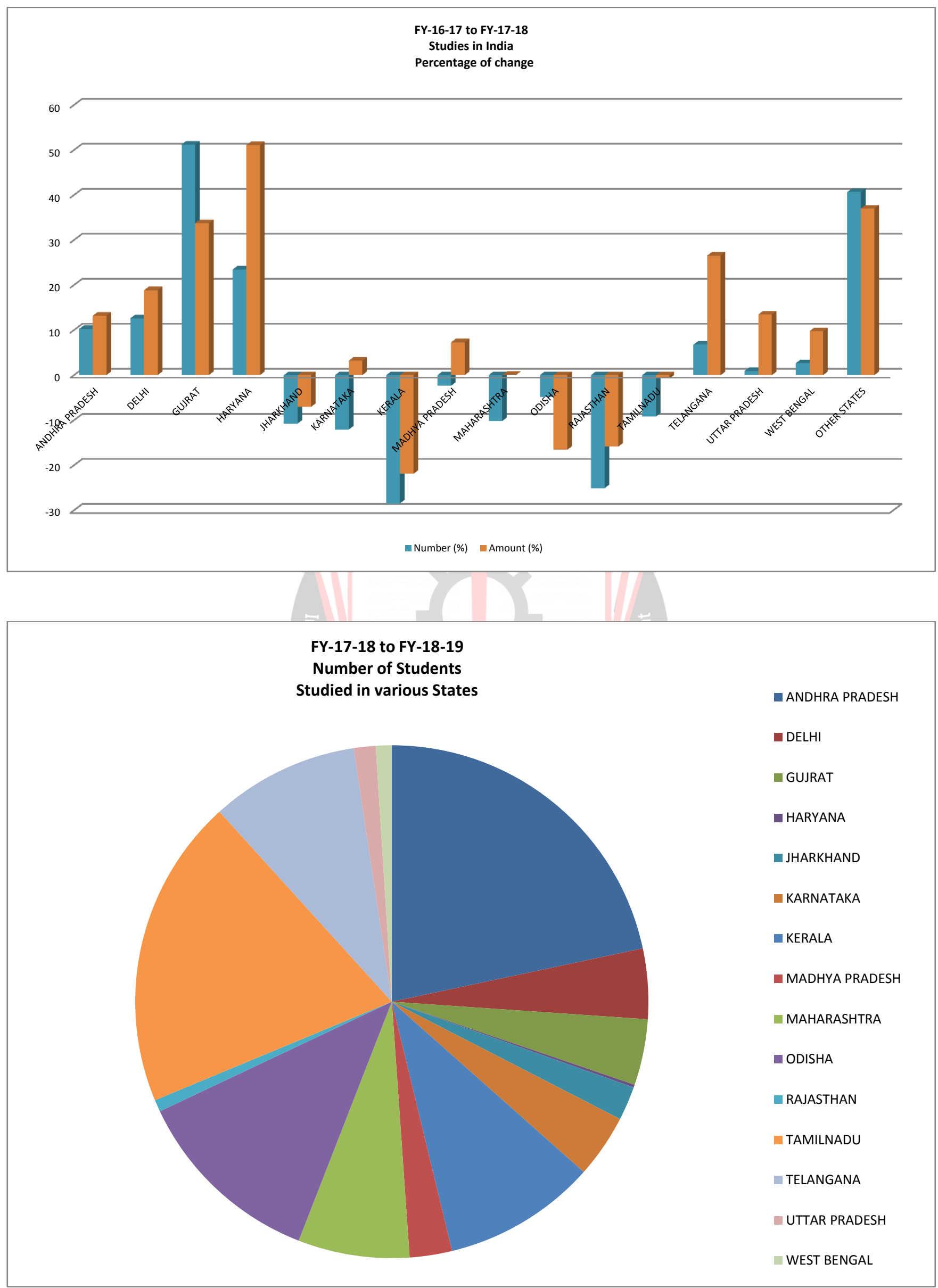
Indian population
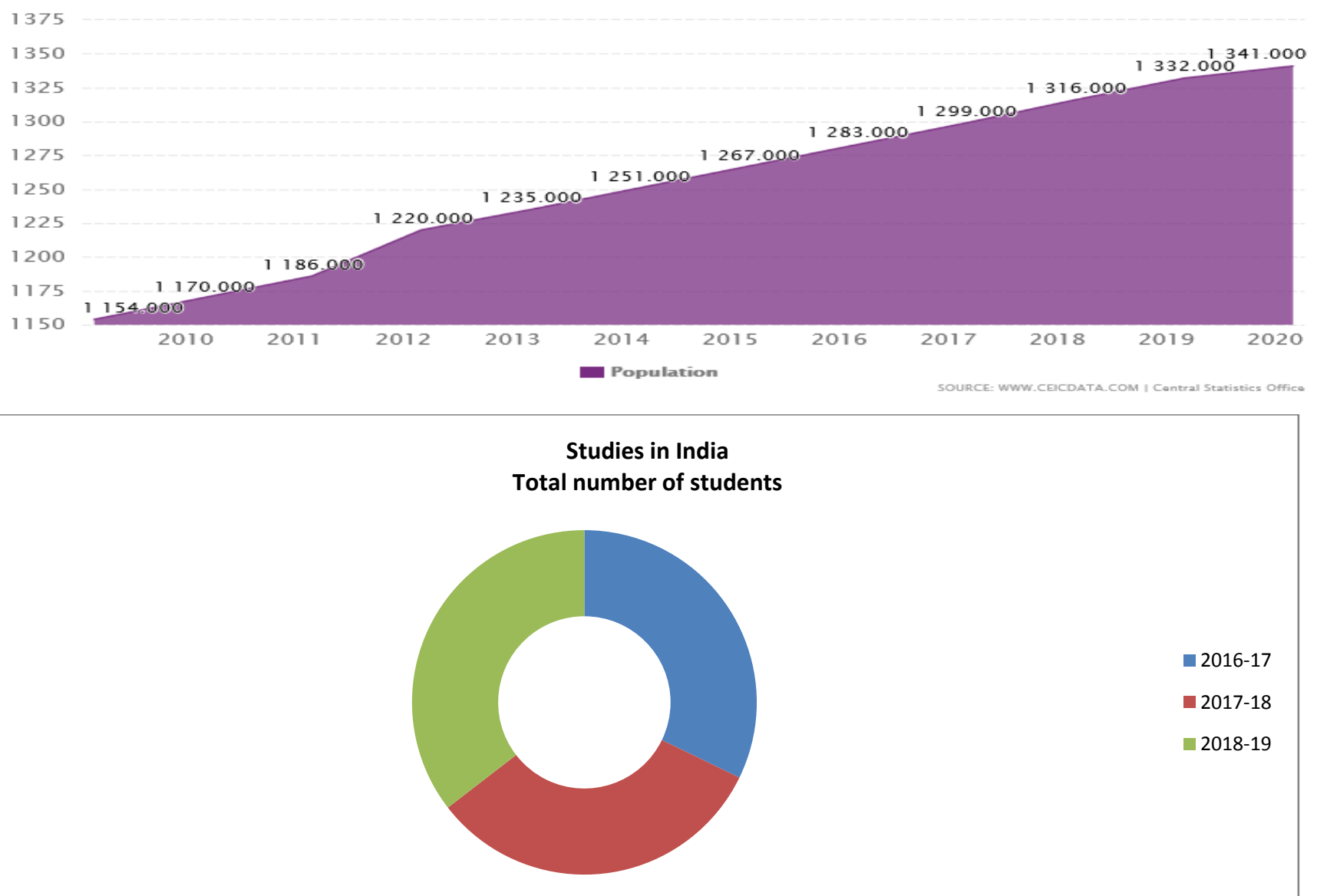

\section{FINDINGS}

The demand for education loan may seem increasing continuously, but the policies to avail this loan are based on a few parameters which make the result move unsteadily. The year-on-year disbursed amount (in crore) was Rs. 2008.42 from SBI during the Financial Year 201617 which dropped to Rs. 1895.64 during the Financial Year 2017-18 which further dropped to Rs. 1609.08 for students studying within India. The amount fluctuates in case of students studying abroad with amount sanctioned being Rs. 2546.11 to Rs. 2456.29 and again raises to Rs. 3430.85 during 2016-17, 2017-18 and 2018-19 respectively. The disbursed amount also saw a similar wave moment of Rs. 2546.11 to Rs. 2456.29 and increased to Rs. 3430.85 during the same period of three Financial Years.

The State-wise study on the number of students and amount sanctioned for Education Loan by State Bank of India reveals that the rate of change from year-to-year has been uneven. The Capital State of India witnessed a rise in the number of students along with States like Andhra Pradesh, Assam, Bihar, Goa, Gujarat, Haryana, Jammu and Kashmir, Telangana, Uttar Pradesh, Uttarakhand and West Bengal shows a positive growth rate while the other states reflect negative rates which shows a decline in amount sanctioned due to reduced number of applicants.
The number of universities in India for higher education during 2016 was 750 and the number of colleges spread across the country was 41435 , which is wavering. The growth rate of higher education in India is not moving parallel with population which is wobbling. The period between 1950 and 2014 reveals the increase in the number of universities by 34 times and 74 times approximate increase in colleges. The quality of education should match the growth rate in higher education, but unfortunately the quantitative aspect is not moving at the same pace as the quality of higher education is concerned. If this space between quality and quantity is matched then nothing can stop India from being the world leader. The policy and planning of Higher Education Sector by MHRD, holds the responsibility of overall development along with infrastructure. The quality aspect needs improvement and needs to plan a development process that can look into the expansion with world class universities and colleges.

The empirical findings reveal the issues involved in educational loan include gender, parent's occupation and income, native place, schooling, marks secured by the students in matriculation and intermediate examination, education cost, placement guarantee, expected salary and interest rate. The marks obtained by the student will decide whether he/she will be eligible for education loan as there is a cut off percentage below which loan will not be sanctioned. The burden of repayment of loan for a student 
will haunt with other factors like dependents in the family and the family financial conditions.

The repayment of education loan seems like a heavy burden for the lender due to existing NPAs in Banks. The risk involved in student borrowers with their financial and demographic situations and the post college employment data lead to high default risk because of unemployment, low salaried jobs that might not be sufficient for the expenditures and repayment of loan. Some cases reveal that the student who is financially sound will also opt for education loan and may drop out of college or may not repay the loan in time as necessary. The attitude of the student to prolong the repayment leads to default risk growing large. This provokes the lender to reconsider the facility given to students with the history of Non Performing Assets already existing may pile up more. The repayment of loan begins after the grace period of the student completing the education and this period may lead to change in mindset of the student leading to nonpayment.

\section{CONCLUSION}

The fees structure from private institutions is very high and thus the cost of higher education becomes critical to balance for students. The government and aided institutions needs to sustain the quality of the education and should balance the proportion of cost of education to the fees structure. In the international measuring scale an approximate recurring cost that can be considered reasonable is 20 percent, when compared to some countries like South Korea, which is 40 percent.

There should be special attention paid to the students from low income background and these students should be sponsored and funded as per the requirement. There can be a policy of guarantee system from the students who come from low income households to avail education loan without parental security to eradicate discrimination arising from the financial status. This is already in practice in United States and may be followed in India as well. The facility of subsidizing the interest rate for students can be organized based on their family income. This innovative financial mechanism needs to be evolved incorporating some of the salient features of the systems existing in UK and USA. The cost of Open Universities should reduce without fluctuations in quality. The technical and vocational education can be treated as the most costeffective way of providing higher education if executed well. The default risk rates may reduce if there is a coborrower or guarantor's presence. The socioeconomic characteristics of borrowers and their regional locations also act as important factors linked with education loan default.

\section{WEBLIOGRAPHY}

https://pib.gov.in/PressReleaseIframePage.aspx?PRID=15 75481

https://www.ugc.ac.in/oldpdf/pub/report/12.pdf

https://www.ceicdata.com/en/indicator/india/population

\section{REFERENCES}

[1] Bandyopadhyay, A. (2016). Studying borrower level risk characteristics of education loan in India. IIMB Management Review 126-135. https://www.sciencedirect.com/science/article/pii/S09 7038961630043X

[2] Kaul, S. (2006, May). Higher education in India: Seizing the opportunity. Indian Council for Research on International Economic Relations, Working Paper no.

https://pdfs.semanticscholar.org/38ad/d0b2a4d9e7d94 01e2502b33778be6ce8a8ad.pdf

[3] Kumar, D. P. (2016, June). Analysis of choice based credit system in higher education. International Journal of Engineering Research and Modern Education (IJERME), Volume I, Issue I.

[4] https://www.researchgate.net/publication/303748309_ Analysis_Of_Choice_Based_Credit_System_In_High er_Education

[5] Lance Lochner, T. S. (2013, Dec). The Importance of Financial Resources for Student Loan Repayment -. NATIONAL BUREAU OF ECONOMIC RESEARCH, Working Paper 19716.

[6] Narayana, M. R. (2005). Student Loan by Commercial Banks: A Way to Reduce State Government Financial Support to Higher Education in India. The Journal of Developing Areas, 38, 171-187.

[7] Panigrahi, J. (2010). Determinants of Educational Loan by Commercial Banks in India. Journal of Educational planning and Administration, XXIV, 379400.

[8] https://www.researchgate.net/publication/317740194_ Determinants_of_Educational_Loan_by_Commercial _Banks_in_India

[9] Rani, P. G. (2014). Education Loans and Financing Higher Education in India: Addressing Equity. Sage Journals https://journals.sagepub.com/doi/pdf/10.1177/234763 1114539891

[10] Singh, A. S. (2018). Accessing higher education in developing countries: Panel data analysis from India, Peru and Vietnam. World Development, 109, 261278.

[11] https://www.younglives.org.uk/content/accessinghigher-education-developing-countries-panel-dataanalysis-india-peru-and-vietnam 